\title{
Steinernema puertoricensis n. sp. (Rhabditida: Steinernematidae), a new entomopathogenic nematode from Puerto Rico, ${ }^{1,2}$
}

\author{
Jessé Román ${ }^{3}$ and Wilfredo Figueroa ${ }^{\prime}$
}

\begin{abstract}
Steinernema puertoricensis $\mathrm{n}$. $\mathrm{sp}_{\text {. }}$ isolated from sand collected from a coconut plantation, can be distinguished from S. glaseri, its most closely related species, by characteristics of the first generation adults. The female has a greater body length $(8.6 \mathrm{~mm})$ and width $(375 \mu \mathrm{m})$. Males have the excretory pore anteriad or posteriad to the nerve ring. Spicules are arcuate and lack a hook at the ventral side of the spicule tip. Infective third-stage juveniles are over $1 \mathrm{~mm}$ in length. This appears to be the first species of Steinernema described from the Caribbean islands and adapted to a hot humid environment.
\end{abstract}

\section{RESUMEN}

Steinernema puertoricensis $\mathrm{n}$. $\mathrm{sp}$. (Rhabditida: Steinernematidae), una nueva especie de nematodo entomopatógeno de Puerto Rico

Steinernema puertoricensis $\mathrm{n}$. $\mathrm{sp}$., aislado de muestras de arena de una plantación de cocos, se puede diferenciar de $S$. glaseri, su especie mas relacionada, por las características de los adultos de la primera generación. La hembra tiene un cuerpo más largo $(8.6 \mathrm{~mm})$ y más ancho $(375 \mu \mathrm{m})$. Los machos tienen localizado el poro excretor anterior o posterior al anillo nervioso. Las espiculas son arqueadas y no poseen una cavidad ventral en su ápice. El cuerpo de los terceros estadios juveniles es de más de $1 \mathrm{~mm}$ de largo. Esta parece ser la primera especie del género descrita de las islas del Caribe y adaptada a un clima cálido y hủmedo.

\section{INTRODUCTION}

The use of entomopathogenic nematodes as biological control agents is acquiring more importance as the deleterious effects of pesticides on animal and human life and the environment become more evident.

'Manuscript submitted to Editorial Board 15 July 1994.

'The authors thank Dr. H. Hirschmann, Depuriment of Plant Pathology, North Carolina State University, Raleigh, N.C. for manuscript review and Dr. G.O. Poinar, Department of Entomological Sciences, University of California, Berkeley, CA, for conducting mating studies.

Professor Emeritus, Department of Crop Protection.

"Associate Nematologist, Department of Crop Protection. 
Species of the genus Steinernema Travassos, 1927 (syn. Neoaplectana Steiner, 1929) are becoming increasingly important as biological control agents. At present, the genus is comprised of 12 species. Poinar (4) listed nine recognized species: S. glaseri Steiner, S. feltiae Filipjev, $S$. affinis Bovien, $S$. carpocapsae Weiser, $S$. anomali Kozodoi, $S$. intermedia Poinar, $S$, rara Doucet (emended Poinar, Mrácek \& Doucet), S. kushidai Mamiya, and S. scapterisci Nguyen \& Smart. Three other species have been described since: $S$. ritteri Doucet \& Doucet (2), S. neocurtilis Nguyen \& Smart (3), and S. riobravis Cabanillas, Poinar \& Raulston (1).

During November 1992 and January 1993, soil samples were collected from different localities in Puerto Rico to determine the presence of entomopathogenic nematodes. A new species, belonging to the family Steinernematidae, was isolated from a soil sample collected at a coconut plantation in the northeastern part of the island. Description of this species, which appears to be the first in the Caribbean islands, is presented herein.

\section{MATERLALS AND METHODS}

Sand collected from a coconut plantation was placed in plastic containers $\left(325 \mathrm{~cm}^{3}\right)$ which were baited with 10 larvae each of the greater wax moth, Galleria mellonella L. and kept in the laboratory at $27^{\circ} \mathrm{C}$. Four days later, dead larvae were placed in White traps (6) and emerging infective third-stage juveniles (IJ) were collected, identified to genus, cultured in Galleria larvae and stored in moist sponges at $16^{\circ} \mathrm{C}$ for further studies.

Life cycle studies were conducted in the laboratory at 27 to $28^{\circ} \mathrm{C}$. One millimeter of distilled water with approximately $2,000 \mathrm{IJ}$ was pipetted into filter paper-lined petri plates $(9 \mathrm{~cm}$ diameter) with live Galleria larvae. Dead larvae were collected and dissected daily. Nematodes recovered were placed in water (except first generation females, which were placed in Ringer solution) on cultured glass slides, killed by gentle heat and mounted in water on glass slides for microscopic study. Measurements and drawings were made within a 6 -hour period by using a compound light microscope with calibrated camera lucida attachment. Nematodes were then fixed in FAA and processed to glycerin according to the method of Thorne (5). Mating studies were conducted by Dr. G. O. Poinar at the Department of Entomological Sciences, University of California, Berkeley, CA. 


\section{SYSTEMATICS}

\section{Steinernema puertoricensis $\mathrm{n}$. sp.}

(Fig. 1 - 2)

Holotype (female, first generation): Length, $7.6 \mathrm{~mm}$; width, $375 \mu \mathrm{m}$; distance from head to excretory pore, $142 \mu \mathrm{m}$; to nerve ring, $200 \mu \mathrm{m}$; to esophagus base, $238 \mu \mathrm{m}$; tail, $45 \mu \mathrm{m}$; vulva $50 \%$.

Female, first generation: Table 1 presents measurements of $10 \mathrm{fe}-$ males. Body spiral shaped when relaxed by gentle heat, cylindroid, tapering anteriad of intestine and posteriad of anus. Body cuticle smooth. Head truncate to slightly rounded, continuous with body contour (Fig. 1 A, 2 A). Labial papillae and lips slightly visible in side view, amphids not observed. Stoma short, lined by protorhabdions. Esophagus muscular, nonvalvated metacorpus slightly swollen, isthmus short, basal bulb slightly enlarged and lumen cavity with refractive ridges, cardia present. Nerve ring surrounding isthmus just anteriad to basal bulb. Excretory pore usually anteriad to nerve ring. Gonads amphidelphic, usually reflexed and filled with eggs that commonly hatch inside the uterus. Vulva a transverse slit protruding from body surface, double-flapped epiptygma present (Fig. 2 B). Vagina short and muscular. Tail usually shorter than anal body width, conical or terminating in a slightly swollen rounded projection (Fig. 1. B).

Pigmy or miniature females, first generation: Table 1 lists measurements of three pigmy females. Body swollen, C-shaped when relaxed by gentle heat. Resembling female but about two and one half times smaller. Uncommon, observed only in one of the three life cycle studies conducted.

Female, second generation: Table 1 lists measurements of $10 \mathrm{fe}-$ males. Resembling female of first generation but about four times smaller (Fig. 1 C-D). Body usually C-shaped when relaxed by gentle heat. Tail conical, about two times longer than anal body width (Fig. 1 D).

Allotype (male, first generation): Length, $1.5 \mathrm{~mm}$; width, $119 \mu \mathrm{m}$; distance from head to excretory pore, $128 \mu \mathrm{m}$; to nerve ring, $109 \mu \mathrm{m}$; to esophagus base, $152 \mu \mathrm{m}$; tail, $31 \mu \mathrm{m}$; spicule, $78 \mu \mathrm{m}$; gubernaculum, 45 $\mu \mathrm{m}$.

Male, first generation: Table 2 lists measurements of 10 males. Resembling female. Body C-shaped and curved posteriorly when relaxed by gentle heat. Cuticle smooth. Head truncate to slightly rounded, continuous with body contour (Fig. 1 E, 2 C). Excretory pore anteriad or 

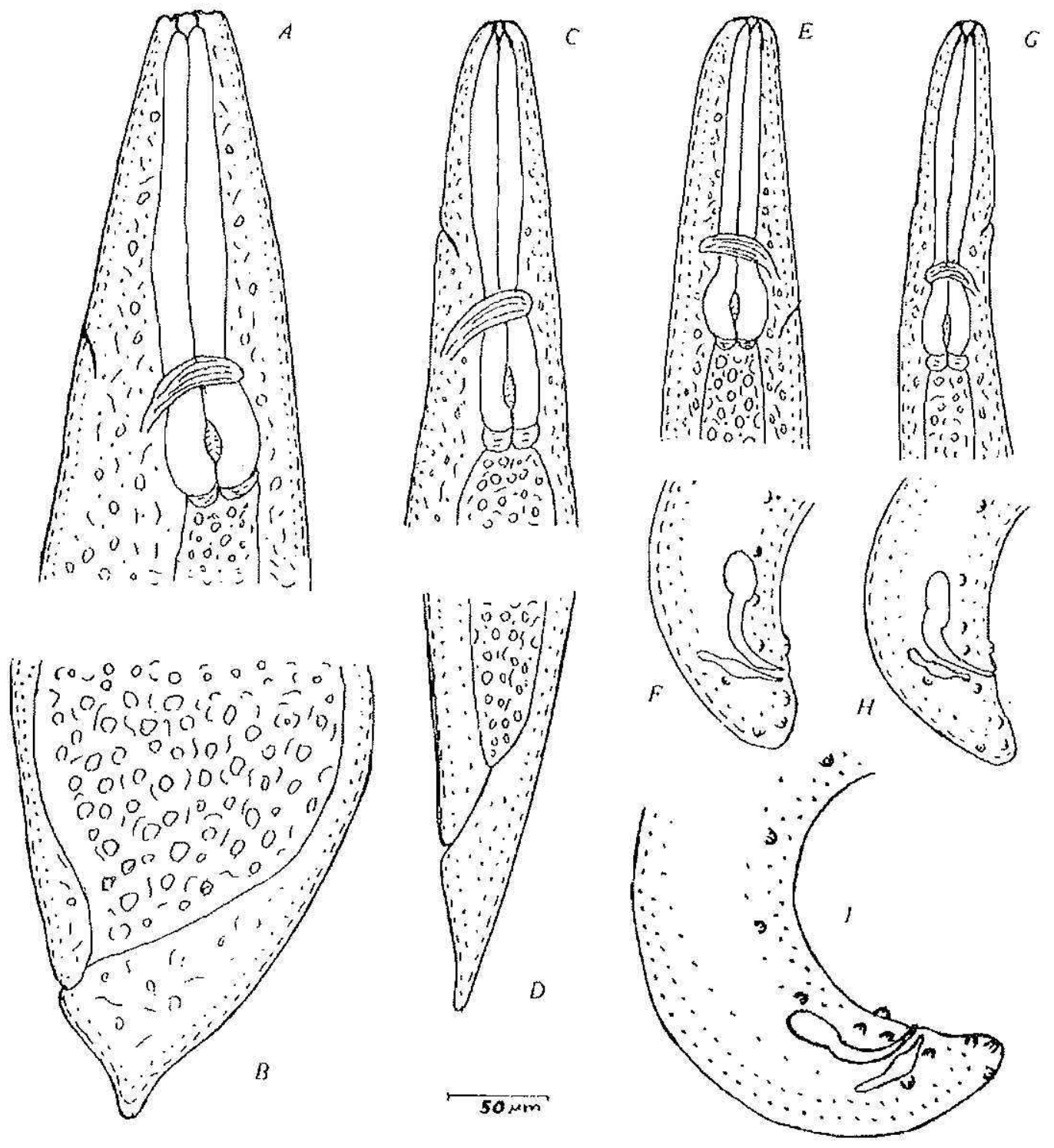

FIG. 1. First and second generation females and males of Steinernema puertoricensis n. sp. A-B) Anterior and posterior region of first generation female. C-D) Anterior and posterior of second generation female. E-F) Anterior and posterior region of first generation male. G.H) Anterior and posterior region of second generation male. I) Posterior region of first generation male showing gevital papillae.

posteriad to nerve ring (Fig. 1 E). Gonad single, reflexed. Spicules paired, symmetrical, arcuate, yellow-orange in color (Fig. $1 \mathrm{~F}, \mathrm{I} ; 2 \mathrm{D}$ ). Distal tips of spicules generally lacking ventral concavity or hook (Fig. $2 \mathrm{D}$ ), which when present is very indistinct. Gubernaculum long, boatshaped (Fig. 1 F,I; 2 D). Male tail with about 23 genital papillae [(seven pairs ventro lateral, three pairs post anal, one pair dorso lateral, and a single ventral adanal) (Fig, 1 I)]. Terminus rounded. Bursa absent. 
TABLE 1.-Measurements $(\mu m)$ of first and second generation females and pigmy females of Steinernema puertoricensis $n . s p$.

\begin{tabular}{|c|c|c|c|c|c|c|c|c|c|}
\hline \multirow[b]{3}{*}{ Character } & \multicolumn{6}{|c|}{ First generation } & & & \\
\hline & \multicolumn{3}{|c|}{ Normal $(N=10)$} & \multicolumn{3}{|c|}{ Pigmy females ( $\mathrm{N}=3$ ) } & \multicolumn{3}{|c|}{ Second generation $(N=10)$} \\
\hline & Mean & S.D. & Range & Mean & S.D. & Range & Mean & S.D. & Range \\
\hline Length & 8,627 & 1,591 & $6,090-11,090$ & 3,666 & 825 & $2,727-4,273$ & 2,256 & 266 & $1,666-2,690$ \\
\hline Width & 375 & 39 & $309-4.54$ & 285 & 38 & $254-327$ & 131 & 17 & $95-162$ \\
\hline Excretory pore & 150 & 35 & $119-236$ & 123 & 22 & $105-148$ & 145 & 16 & $119-169$ \\
\hline Nerve ring & 193 & 32 & $162-269$ & 168 & 23 & $152-195$ & 154 & 11 & $138-169$ \\
\hline Esophagus & 249 & 26 & $217-298$ & 204 & 15 & $193-221$ & 189 & 9 & $176-202$ \\
\hline Tail & 59 & 11 & $40-74$ & 41 & 25 & 21-69 & 83 & 8 & $74-98$ \\
\hline Vulva & 50 & 4 & $40-53$ & 50 & 3 & $47-53$ & 53 & 3 & $47-57$ \\
\hline
\end{tabular}


Male, second generation: Table 2 lists measurements of 10 males. Resembling male of first generation but slightly smaller (Fig. $1 \mathrm{G}-\mathrm{H}$ ). Excretory pore anteriad to nerve ring.

Juvenile, infective third-stage (IJ): Table 3 lists measurements of 10 juveniles. Third-stage juveniles usually enclosed in second stage cuticle. Body narrow and long (more than $1 \mathrm{~mm}$ long). Mouth and anus generally closed. Pharynx and intestine usually indistinct. Lateral field composed of six incisures. Tail pointed, twice as long as body width.

Development: The studies conducted demonstrated that $S$. puertoricensis enters larvae of $G$. mellonella and completes its life cycle in 5 days at 27 to $28^{\circ} \mathrm{C}$. It took 2 days for the IJ to enter, kill the host and develop into first generation males and females. Second generation adults appeared 4 days after infection. Infective juveniles began emerging 5 days after infection.

Type locality

Sand from coconut plantation at, Loíza, Puerto Rico. Type specimens

Holotype: First generation female (in glycerin) isolated from sand of coconut plantation at Loíza, P. R. Slide number 1, deposited in the United States Department of Agriculture Nematode Collection (USDANC), Beltsville, Maryland. Allotype: First generation male (in glycerin). Same data as holotype. Slide number 2, deposited in the USDANC, Beltsville, Md. Paratypes: First generation adults and third stage juveniles (in glycerin). Same data as holotype. First generation females, vial number 1 ; first generation males, vial number 2 ; thirdstage juveniles, vial number 3; deposited in the USDANC, Beltsville, $\mathrm{Md}$.

TABLE 2.-Measurements ( $\mu m$ ) of first and second generation males of Steinernema puertoricensis n. sp.

\begin{tabular}{lrrrrrrr}
\hline & \multicolumn{3}{c}{ First generation $(N=10)$} & & \multicolumn{2}{c}{ Second generation $(N=10)$} \\
\cline { 2 - 5 } \cline { 6 - 7 } Character & Mean & S.D. & Range & Mean & S.D. & Range \\
\hline Length & 1,461 & 165 & $1,214-1,667$ & 1,203 & 46 & $1,119-1,262$ \\
Width & 101 & 21 & $67-143$ & 64 & 4 & $57-67$ \\
Excretory pore & 123 & 14 & $95-143$ & 122 & 6 & $112-133$ \\
Nerve ring & 122 & 13 & $98-138$ & 131 & 6 & $124-143$ \\
Esophagus & 159 & 12 & $143-178$ & 166 & 4 & $157-171$ \\
Tail & 34 & 5 & $24-43$ & 37 & 3 & $33-40$ \\
Spicule & 78 & 5 & $71-88$ & 63 & 8 & $48-71$ \\
Gubernaculum & 40 & 3 & $36-45$ & 34 & 3 & $28-36$ \\
\hline
\end{tabular}



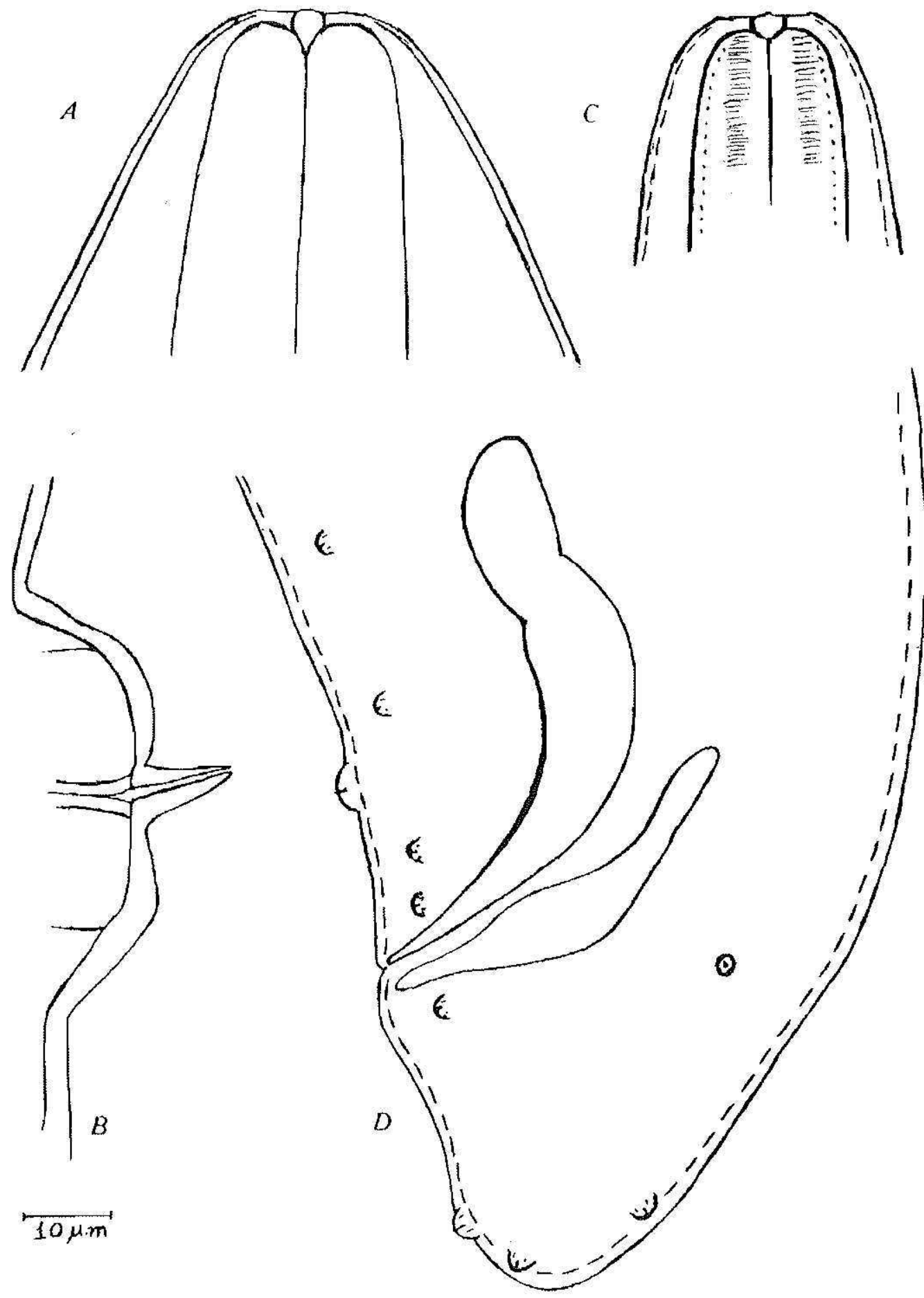

FiG. 2. First generation female and male of Steinernema puertoricensis n. sp. A) Anterior region of first generation female. B) Vulva region of female showing double flapped epiptygma. C) Anterior region of male. D) Posterior region of male showing spicule and gubernaculum. 
Table 3-Measurements $(\mu \mathrm{m})$ of third-stage juveniles $\left(\chi_{d}\right)$ of Steinernema puertoricensis n. $s p .(N=10)$.

\begin{tabular}{lccc}
\hline Character & Mean & S.D. & Range \\
\hline Length & 1,171 & 60 & $1,057-1,238$ \\
Width & 51 & 2 & $47-54$ \\
Excretory pore & 95 & 4 & $90-102$ \\
Nerve ring & 117 & 4 & $111-121$ \\
Esophagus & 143 & 3 & $138-147$ \\
Tail & 94 & 6 & $88-107$ \\
Ratio A' & 23 & 1 & $20-24$ \\
Ratio B & 8.2 & 0.4 & $7.4-8.6$ \\
Ratio $C^{3}$ & 12.4 & 0.8 & $11.6-13.6$ \\
Ratio $\mathrm{D}^{-1}$ & 0.66 & 0.03 & $0.62-0.74$ \\
Ratio $\mathrm{E}^{;}$ & 1.01 & 0.07 & $0.88-1.08$ \\
Ratio $\mathrm{F}^{\prime \prime}$ & 0.54 & 0.04 & $0.48-0.60$ \\
\hline
\end{tabular}

Tength/width.

Length/distance from head to esophagus base.

"Length/tail length.

-1Distance from head to excretory pore/distance from head to esophagus base.

Distance from head to excretory pore/tail length.

"Width/tail length.

Diagnosis: First generation females with large wide body, males with excretory pore anteriad or posteriad to nerve ring, spicules lacking a terminal ventral hook, arcuate. Infective third-stage juveniles over $1 \mathrm{~mm}$ in length, with smaller esophagus and Ratio $\mathrm{A}$ value and greater tail length.

Relationships: Steinernema puertoricensis can be distinguished from its most closely related species, $S$. glaseri, by the greater body length of the first generation females: $8.6 \mathrm{~mm}$, range: $6.1-11.1(5.6 \mathrm{~mm}$, range: 4.0-7.9 for $S$. glaseri) and greatest width: $375 \mu \mathrm{m}$, range: 309 $400(236 \mu \mathrm{m}$, range: $180-300$ for $S$. glaseri $)$. The first generation males of $S$. puertoricensis have the excretory pore anteriad or posteriad to nerve ring, as compared with $S$. glaseri where the excretory pore is always posteriad to the nerve ring. Second generation males have a larger tail: $37 \mu \mathrm{m}$, range: $33-40$ ( $28 \mu \mathrm{m}$, range: $25-31$ for $S$. glaseri). Steinernema puertoricensis males usually lack the hook located at the ventral side of the spicule tip, characteristic of $S$. glaseri, and spicules are distinctly arcuate. Infective third-stage juveniles have shorter esophagus: $143 \mu \mathrm{m}$, range: $138-147$ (162 $\mu \mathrm{m}$, range: $158-168$ for $S$. glaseri), greater tail length: $94 \mu \mathrm{m}$, range: $88-107$ (78 $\mu \mathrm{m}$, range: $62-87$ for 
S. glaseri), and smaller Ratio A value: 23 , range: $20-24$ (29, range: $26-$ 35 for $S$. glaseri). Mating studies between the two species failed to produce a progeny (Poinar, personal communication).

\section{DISCUSSION}

Steinernema puertoricensis $\mathrm{n}$. $\mathrm{sp}$. was isolated from sand and therefore its insect host is unknown. Laboratory and greenhouse studies revealed the high virulence of $S$. puertoricensis to larvae of the greater wax moth, Galleria mellonella, and adults of the family Scarabaeidae, e. g., Phyllophaga portoricensis Smyth, $P$. vandinei Smyth and $P$. citri Smyth. The latter three species are important agricultural pests of sugarcane, corn, root crops, fruits and ornamental plants.

The fact that $S$. puertoricensis $\mathrm{n}$. sp. was found in Puerto Rico may indicate that other species of the genus can be present in Puerto Rico and other Caribbean islands attacking not only the above mentioned insect species, but also others belonging to different genera and species. Studies related to this matter are underway.

\section{LITERATURE CITED}

1. Cabanilias, H.E., G.O. Polnar, Jx. and J.R. Raulston, 1994. Steinernema riobravis n. sp. (Rhabditida: Steinernematidae) fiom Texas. Fundamental and Applied Nematology 17:123-131.

2. Doucet, M.M.A. and M.E. Doucet, 1990. Steinernema ritteri $n$. sp. (Nematoda: Steinernematidae) with a key to the species of the genus. Nematologica 36:257-265.

3. Nguyen, K.B. and G.C. Smart, Jr., 1992. Steinernema neocurtilis n. sp. (Rhabditida: Steinernematidae) and a key to species of the genus Steinernema, d. Nematol. 24: 463-477.

4. Poinar, G.O., Jr., 1990. Taxonomy and biology of Steinernematidae and Heterorhabditidae. In: R. Gaugler and H.K. Kaya, eds. Entomopathogenic Nematodes in Biological Control. Boca Raton, FL. CRC Press.

5. Thorne, G., 1961. Principles of Nematology. MeGraw-Hill Co. Inc., N.Y.

6. White, G.F., 1927. A method for obtaining infective nematode tarvae from cultures. Science 60:302-330. 